\title{
Effect of Music Therapy for Anxiety in Children
}

\author{
B. Aishwarya Reddy and Mebin George Mathew ${ }^{2}$ \\ ${ }^{1}$ Saveetha Dental College and Hospitals, Saveetha Institute of Medical and Technical Sciences, \\ Saveetha University, Chennai, 600077, India \\ ${ }^{2}$ Senior Lecturer, Department of Pedodontics and Preventive Dentistry, Saveetha Dental College and Hospitals, \\ Saveetha Institute of Medical and Technical Sciences, Saveetha University, Chennai-600077, India
}

\section{ABSTRACT}

Dental anxiety has been identified as a significant problem in both children and adults and is considered an obstacle in the provision of quality dental care by dental care providers. Music is an alternate treatment option which has been used in different medical fields. Suitable music has been shown to have a strong influence on human brain waves. The aim of the study is to estimate the effect of music therapy for anxiety in children. 60 children aged 7-9years were divided into two groups, Group I: treatment without music and Group II: treatment with music. The treatment done for the children included scaling and pit and fissure sealant application. The method followed for this study was the coin toss method. The analysis was done using SPSS software.The results showed that the pulse rate in children treated with music is decreased. The systolic and diastolic blood pressure is also decreased in children treated with music. A drastic variation was observed in the pulse rate, systolic blood pressure and diastolic blood pressure. Within the limits of the study, music therapy helps children with anxiety.

KEY WORDS: ANXIETY; CHILDREN; MUSIC THERAPY; PULSE RATE.

\section{INTRODUCTION}

Dental anxiety can be defined as a state where an individual is evoked and prepared for something to happen, with a non-specific feeling of apprehension, associated with abnormal conditions((Nagaveni, Yadav and Poornima, 2017; Neena et al., 2017). The etiology of dental anxiety can be attributed to traumatic or painful dental experiences as well as fearful attitudes learnt from dentally anxious family members (Locker, Liddell and Shapiro, 1999; Maulina, Djustiana and

\section{ARTICLE INFORMATION}

${ }^{*}$ Corresponding Author: mebingeorgem.sdc@saveetha.com Received 12th June 2020 Accepted after revision 10th August 2020 Print ISSN: 0974-6455 Online ISSN: 2321-4007 CODEN: BBRCBA

Thomson Reuters ISI Web of Science Clarivate Analytics USA and Crossref Indexed Journal

\section{Clarivate
Analytics}

NAAS Journal Score 2020 (4.31) SJIF: 2020 (7.728)

A Society of Science and Nature Publication,

Bhopal India 2020. All rights reserved.

Online Contents Available at: http//www.bbrc.in/

Doi: http://dx.doi.org/10.21786/bbrc/13.7/60
Nurhalim Shahib, 2017). ('Advances in pain and anxiety management', 2012). Regardless of the classification of dental anxiety, patients with dental anxiety will show some refusal symptoms during treatment. These refusal symptoms of anxiety, can be classified into physiological symptoms, behavioural symptoms, cognitive symptoms, and emotional symptoms (Shives, 1995).

Music surrounds our lives. We hear it on the radio, television, our cars, and home stereos. Even warbling in our bathroom gives us a happy start of the day. Music is also clinically recognized to influence biological responses such as blood pressure, heart rate, respiratory rate, cardiac output, muscle tone, papillary responses, skin responses, and endorphin production. It can entrain the body to calm or to accelerate, depending on the type of music used (Stabholz and Peretz, 1999). Sedative music can lower the anxiety, pain, tension ((Nagaveni, Poornima and Bajaj, 2019; Nagaveni, Poornima and Mathew, 2020) 
and stress levels resulting in less use of anesthetics and pain medication, distraction from thoughts, and higher patient compliance and satisfaction(Corah, Gale and Illig, 1978). By definition, music therapy is the systematic application of music in the treatment of physiological and psychological aspects of an illness or disability. (Fukayama and Yagiela, 2006)

One effective method of providing support for anxiety in children is music therapy, where music becomes the main tool the therapist uses to connect and work with the patient. This kind of therapy has been shown to be effective when treating children and young people living with anxiety based disorders (British Association for Music Therapy, no date). Saarikallio and Erkkilä, 2007).

Music reduces anxiety through its effect on the autonomic nervous responses which regulates bodily functions such as the heart rate, digestion, respiratory rate and pupillary response (Packyanathan, Lakshmanan and Jayashri, 2019).(Chlan, 1998). Several studies have demonstrated reduction in cortisol and other hypothalamic-pituitaryadrenal axis neuropeptides following music listening. This triggers the limbic system releasing endorphins which minimizes discomfort and pain and maximise pleasure (Cooke et al., 2005), (Labrague and McEnroePetitte, 2016).

Our department is passionate about child care, we have published numerous high quality articles in this domain over the past 3 years (Govindaraju, Jeevanandan and Subramanian, 2017a, 2017b; Panchal, Gurunathan and Shanmugaavel, 2017; Ravikumar, Jeevanandan and Subramanian, 2017; Jeevanandan and Govindaraju, 2018; Nair et al., 2018; Ravikumar et al., 2018, 2019; Ravindra et al., 2018, 2019; Subramanyam et al., 2018; Vishnu Prasad et al., 2018; Jeevanandan, Ganesh and Arthilakshmi, 2019; Ramadurai et al., 2019; Ramakrishnan, Dhanalakshmi and Subramanian, 2019; Veerale Panchal, Jeevanandan and Subramanian, 2019; Vignesh et al., 2019; V. Panchal, Jeevanandan and Subramanian, 2019; Samuel, Acharya and Rao, 2020). With this inspiration we planned to pursue research on the effect of music therapy for anxiety in children.

\section{MATERIAL AND METHODS}

In this study, a sample size of 60 children of 7 to 9 years of age who have visited Saveetha Dental College and Hospitals, were randomly selected and were equally divided into two groups. Group I: treatment without music(control group) and Group II: treatment with music(test group). The treatment done for the children included only scaling and pit and fissure sealant application. The subjects were made to choose their own choice of music and were given headphones during the treatment. The pulse rate, systolic and diastolic blood pressure were noted for both the groups before and after the treatment. The analysis was performed using SPSS software by IBM. The mean and standard deviations were calculated for the pulse rate, systolic and diastolic blood pressure, both before and after the treatment. The Pearson's correlation test was performed to correlate the changes in the pulse rate, systolic and diastolic blood pressure before and after the treatment in both the groups.

\section{RESULTS AND DISCUSSION}

The aim of this study was to estimate the effect of music therapy for anxiety in children. The study results showed that, out of 60 samples, 30 samples are of the control group(Group I) where there were 16 boys(53.4\%) and 14 girls(46.7\%). The test group also had 30 samples where there were 17 boys(56.7\%) and 13 girls(43.4\%). All the samples were from the age group of 7 to 9 years (Table 1).

\begin{tabular}{|c|c|c|c|}
\hline PARAMETER & $\begin{array}{c}\text { CONTROL } \\
\text { GROUP }\end{array}$ & $\begin{array}{c}\text { TEST } \\
\text { GROUP }\end{array}$ & $\begin{array}{c}\text { P } \\
\text { VALUE }\end{array}$ \\
\hline AGE (years) & $7.1 \pm 0.7$ & $7.2 \pm 0.9$ & 0.712 \\
\hline \multirow[t]{2}{*}{ SEX } & Male - 16(53.4) & Male - 17(56.7) & \\
\hline & Female - 14(4.7) & Female- 13(43.4) & 0.795 \\
\hline
\end{tabular}

Before the treatment, the pulse rate in the control group is $102.4 \pm 15.8$ and the test group is $100.5 \pm 15.4$ where the $\mathrm{p}$ value is 0.763 which is statistically insignificant. The systolic blood pressure in control group is $124.0 \pm 12.2$ and the test group is $122.3 \pm 12.5$, which is statistically insignificant ( $\mathrm{P}=0.697$ ). The diastolic blood pressure in the control group is $81.2 \pm 10.8$ and the test group is 79.7 \pm 12.6 , where the $p$ value is 0.654 which is statistically insignificant (Table 2).

Table 2. Pulse rate,SBP, DBP, in control and test group before treatment

\begin{tabular}{l|c|c|c|}
\hline VARIABLE & $\begin{array}{c}\text { CONTROL } \\
\text { GROUP }\end{array}$ & $\begin{array}{c}\text { TEST } \\
\text { GROUP }\end{array}$ & $\begin{array}{c}\text { P } \\
\text { VALUE }\end{array}$ \\
\hline PULSE RATE & $102.4 \pm 15.8$ & $100.5 \pm 15.4$ & 0.763 \\
\hline SBP & $124.0 \pm 12.2$ & $122.3 \pm 12.5$ & 0.697 \\
\hline DBP & $81.2 \pm 10.8$ & $79.7 \pm 12.6$ & 0.654 \\
\hline
\end{tabular}

After the treatment, the pulse rate in the control group is $107.4 \pm 19.8$ and the test group is $87.1 \pm 12.1$, where the $p$ value is 0.001 which is statistically significant. The systolic blood pressure in the control group is $127.8 \pm 9.5$ and the test group is $118.8 \pm 12.1$, which is statistically significant ( $\mathrm{P}=0.004)$. The diastolic blood pressure in the control group is $83.4 \pm 8.0$ and the test group is 78.2 \pm 12.5 , where the $p$ value is 0.234 which is statistically insignificant ( Table 3).

In this study, it was observed that the pulse rate was decreased after the treatment in the test group when 
compared to the control group. In the study given by Marwah N, et.al, 2005 (Marwah, Prabhakar and Raju, 2005), pulse rate is decreased in pediatric dental patients who were subjected to audio distraction but not to a very significant level. Audio distraction is one such nonaversive technique in which a patient listens to music during the dental procedure. Because of its success in medical settings and in adult dental patients many dentists believe that this technique may be successful in management of pediatric dental patients ((Mathew et al., 2020; Mathew, Roopa and Soni, 2020). This study shows similar ethnicity to the present study.

Table 3. Pulse rate,SBP, DBP, in control and test group after treatment

\begin{tabular}{|l|c|c|c|}
\hline VARIABLE & $\begin{array}{c}\text { CONTROL } \\
\text { GROUP }\end{array}$ & $\begin{array}{c}\text { TEST } \\
\text { GROUP }\end{array}$ & $\begin{array}{c}\text { P } \\
\text { VALUE }\end{array}$ \\
\hline PULSE RATE & $107.4 \pm 19.8$ & $87.1 \pm 12.1$ & 0.001 \\
\hline SBP & $127.8 \pm 9.5$ & $118.8 \pm 12.1$ & 0.004 \\
\hline DBP & $83.4 \pm 8.0$ & $78.2 \pm 12.5$ & 0.234 \\
\hline
\end{tabular}

In the current study it was observed that the systolic blood pressure is found to be lower in the test group after the treatment than the diastolic blood pressure. In the study given by Dviya Singh, et.al, 2014 (Singh et al., 2014), Systolic blood pressure was found to be lower in music group than DBP which was not having significant variations between both the groups. The study given by Mimi M Y, et.al, 2005 (Tse, Chan and Benzie, 2005), also shows that systolic blood pressure is slightly lower than the diastolic blood pressure.Both the studies show similar findings with the present study. When exposed to slow beat music the parasympathetic nervous system is stimulated decreasing the heart rate and while listening to fast beat music the sympathetic nervous system is stimulated and increases the heart rate. (Mathew, 2020a, 2020b)

The salivary cortisol values before the treatment in both the groups is statistically insignificant where the $p$ value is 0.924 . And the $p$ value of salivary cortisol after the treatment is 0.001 which is statistically significant( Table 4).

Table 4. Salivary Cortisol values in control and test group

\begin{tabular}{|l|c|c|c|}
$\begin{array}{l}\text { SALIVARY } \\
\text { CORTISOL }\end{array}$ & $\begin{array}{c}\text { CONTROL } \\
\text { GROUP }\end{array}$ & $\begin{array}{c}\text { TEST } \\
\text { GROUP }\end{array}$ & $\begin{array}{c}\text { P } \\
\text { VALUE }\end{array}$ \\
\hline $\begin{array}{l}\text { BEFORE } \\
\text { TREATMENT }\end{array}$ & $\begin{array}{c}1.64 \pm 1.31 \\
\mathrm{ug} / \mathrm{dl}\end{array}$ & $\begin{array}{c}1.59 \pm 1.24 \\
\mathrm{ug} / \mathrm{dl}\end{array}$ & 0.924 \\
\hline AFTER & $\begin{array}{c}5.33 \pm 1.72 \\
\mathrm{ug} / \mathrm{dl}\end{array}$ & $\begin{array}{c}1.79 \pm 2.04 \\
\mathrm{ug} / \mathrm{dl}\end{array}$ & 0.001 \\
TREATMENT & & & \\
\hline
\end{tabular}

While the use of music has been explored within various clinical settings in both medicine and dentistry, the evidence-base for its use in reducing dental anxiety in children remains inconclusive and of limited quality ((Mathew and Soni, 2019).

\section{CONCLUSION}

Within the limits of our study we conclude that music therapy reduced anxiety in children. Hence music therapy is significant in reducing anxiety in children visiting dental clinics. However more studies should be done to explore the various reasons and treatment planning for pediatric dental patients with anxiety. This study will act as a guide to understand the effect of music therapy for anxiety in children.

\section{ACKNOWLEDGEMENTS}

All the authors have equally contributed to this study.

Conflict of Interest: None to declare

\section{REFERENCES}

'Advances in pain and anxiety management' (2012) Dental Abstracts, pp. 192-193. doi: 10.1016/j. denabs.2011.11.026.

British Association for Music Therapy (no date). Available at: https://www.bamt.org/ (Accessed: 30 June 2020).

Chlan, L. (1998) 'Effectiveness of a music therapy intervention on relaxation and anxiety for patients receiving ventilatory assistance', Heart \&t lung: the journal of critical care, 27(3), pp. 169-176.

Cooke, M. et al. (2005) 'The effect of music on preoperative anxiety in day surgery', Journal of Advanced Nursing, pp. 47-55. doi: 10.1111/j.13652648.2005.03563.x.

Corah, N. L., Gale, E. N. and Illig, S. J. (1978) 'Assessment of a dental anxiety scale', Journal of the American Dental Association , 97(5), pp. 816-819.

Fukayama, H. and Yagiela, J. A. (2006) 'Monitoring of vital signs during dental care', International dental journal, 56(2), pp. 102-108.

Govindaraju, L., Jeevanandan, G. and Subramanian, E. M. G. (2017a) 'Comparison of quality of obturation and instrumentation time using hand files and two rotary file systems in primary molars: A single-blinded randomized controlled trial', European journal of dentistry, 11(3), pp. 376-379.

Govindaraju, L., Jeevanandan, G. and Subramanian, E. M. G. (2017b) 'Knowledge and practice of rotary instrumentation in primary teeth among indian dentists: A questionnaire survey', Journal of International Oral Health, 9(2), p. 45.

Jeevanandan, G., Ganesh, S. and Arthilakshmi (2019) 'Kedo file system for root canal preparation in primary teeth', Indian journal of dental research: official 
publication of Indian Society for Dental Research, 30(4), pp. 622-624.

Jeevanandan, G. and Govindaraju, L. (2018) 'Clinical comparison of Kedo-S paediatric rotary files vs manual instrumentation for root canal preparation in primary molars: a double blinded randomised clinical trial', European archives of paediatric dentistry: official journal of the European Academy of Paediatric Dentistry, 19(4), pp. 273-278.

Labrague, L. J. and McEnroe-Petitte, D. M. (2016) 'Influence of Music on Preoperative Anxiety and Physiologic Parameters in Women Undergoing Gynecologic Surgery', Clinical Nursing Research, pp. 157-173. doi: 10.1177/1054773814544168.

Locker, D., Liddell, A. and Shapiro, D. (1999) 'Diagnostic categories of dental anxiety: a population-based study', Behaviour Research and Therapy, pp. 25-37. doi: 10.1016/s0005-7967(98)00105-3.

Marwah, N., Prabhakar, A. R. and Raju, O. S. (2005) 'Music distraction--its efficacy in management of anxious pediatric dental patients', Journal of the Indian Society of Pedodontics and Preventive Dentistry, 23(4), pp. 168-170.

Mathew, M. G. et al. (2020) 'Evaluation of adhesion of Streptococcus mutans, plaque accumulation on zirconia and stainless steel crowns, and surrounding gingival inflammation in primary ..., Clinical oral investigations. Springer. Available at: https://link.springer.com/ article/10.1007/s00784-020-03204-9.

Mathew, M. G. (2020a) 'Management of a pediatric patient with ataxia telangiectasia: Report of a rare case in which diagnostic radiographs are contraindicated', Journal of Family Medicine and Primary Care. ncbi. nlm.nih.gov. Available at: https://www.ncbi.nlm.nih. gov/pmc/articles/PMC7113957/.

Mathew, M. G. (2020b) 'Management of siblings with Glanzmann's thrombasthenia: A case report', Journal of Family Medicine and Primary Care. ncbi.nlm.nih. gov. Available at: https://www.ncbi.nlm.nih.gov/pmc/ articles/PMC7266179/.

Mathew, M. G., Roopa, K. B. and Soni, A. J. (2020) 'Evaluation of clinical success, parental and child satisfaction of stainless steel crowns and zirconia crowns in primary molars', Journal of Family. ncbi. nlm.nih.gov. Available at: https://www.ncbi.nlm.nih. gov/pmc/articles/PMC7266243/.

Mathew, M. G. and Soni, A. J. (2019) 'Prevalence of three-rooted primary mandibular first molars in Karnataka (South Indian) population', International Journal of Pedodontic Rehabilitation. Medknow Publications and Media Pvt. Ltd., 4(1), p. 6.

Maulina, T., Djustiana, N. and Nurhalim Shahib, M. (2017) 'The Effect of Music Intervention on Dental
Anxiety During Dental Extraction Procedure', The open dentistry journal. Bentham Science Publishers, 11, p. 565.

Nagaveni, N. B., Poornima, P. and Bajaj, M. (2019) 'Revascularization of a Nonvital, Immature Permanent Tooth Using Amniotic Membrane: A Novel Approach', Journal of Clinical .... ncbi.nlm.nih.gov. Available at: https://www.ncbi.nlm.nih.gov/pmc/articles/ PMC6749878/.

Nagaveni, N. B., Poornima, P. and Mathew, M. G. (2020) 'A Comparative Evaluation of Revascularization Done in Traumatized Immature, Necrotic Anterior Teeth with and without Platelet-rich Fibrin: A Case Report', Journal of Clinical .... ncbi.nlm.nih.gov. Available at: https:// www.ncbi.nlm.nih.gov/pmc/articles/PMC7299885/.

Nagaveni, N. B., Yadav, S. and Poornima, P. (2017) 'Volumetric evaluation of various obturation techniques in primary teeth using cone beam computed tomography-An in vitro study', Journal of Indian. jisppd.com. Available at: http://www.jisppd.com/article. asp?issn $=0970-4388 ;$ year $=2017$; volume $=35 ;$ issue $=3 ;$ sp age $=244$; epage $=248$; aulast $=$ Nagaveni .

Nair, M. et al. (2018) 'Comparative evaluation of postoperative pain after pulpectomy with k-files, kedo-s files and mtwo files in deciduous molars -a randomized clinical trial', Brazilian Dental Science, 21(4), p. 411.

Neena, I. E. et al. (2017) 'Management of maxillary anterior supernumerary teeth', Astrocyte. astrocyte. in. Available at: http://www.astrocyte.in/article. asp?issn $=2349-0977$; year $=2017$; volume $=3 ;$ issue $=4 ;$ sp age $=231$; epage $=233$; aulast $=$ Neena .

Packyanathan, J. S., Lakshmanan, R. and Jayashri, P. (2019) 'Effect of music therapy on anxiety levels on patient undergoing dental extractions', Journal of Family Medicine and Primary Care. Medknow Publications and Media Pvt. Ltd., 8(12), p. 3854.

Panchal, V., Gurunathan, D. and Shanmugaavel, A. K. (2017) 'Smartphone application as an aid in determination of caries risk and prevention: A pilot study', European journal of dentistry, 11(4), pp. 469474.

Panchal, V., Jeevanandan, G. and Subramanian, E. (2019) 'Comparison of instrumentation time and obturation quality between hand K-file, H-files, and rotary Kedo-S in root canal treatment of primary teeth: A randomized controlled trial', Journal of the Indian Society of Pedodontics and Preventive Dentistry, 37(1), pp. 75-79.

Panchal, V., Jeevanandan, G. and Subramanian, E. M. G. (2019) 'Comparison of post-operative pain after root canal instrumentation with hand $\mathrm{K}$-files, $\mathrm{H}$-files and rotary Kedo-S files in primary teeth: a randomised clinical trial', European archives of paediatric dentistry: 
official journal of the European Academy of Paediatric Dentistry, 20(5), pp. 467-472.

Ramadurai, N. et al. (2019) 'Effectiveness of 2\% Articaine as an anesthetic agent in children: randomized controlled trial', Clinical oral investigations, 23(9), pp. 3543-3550.

Ramakrishnan, M., Dhanalakshmi, R. and Subramanian, E. M. G. (2019) 'Survival rate of different fixed posterior space maintainers used in Paediatric Dentistry - A systematic review', The Saudi dental journal, 31(2), pp. 165-172.

Ravikumar, D. et al. (2018) 'DNA profiling of Streptococcus mutans in children with and without black tooth stains: A polymerase chain reaction analysis', Dental research journal, 15(5), p. 334.

Ravikumar, D. et al. (2019) 'Evaluation of McNamara's analysis in South Indian (Tamil Nadu) children between 8-12 years of age using lateral cephalograms', Journal of oral biology and craniofacial research, 9(2), pp. 193-197.

Ravikumar, D., Jeevanandan, G. and Subramanian, E. M. G. (2017) 'Evaluation of knowledge among general dentists in treatment of traumatic injuries in primary teeth: A cross-sectional questionnaire study', European journal of dentistry, 11(2), pp. 232-237.

Ravindra, V. et al. (2018) 'A comparative evaluation between dermatoglyphic patterns and different terminal planes in primary dentition', Journal of clinical and experimental dentistry, 10(12), pp. e1149-e1154.

Ravindra, V. et al. (2019) 'A comparative evaluation between cheiloscopic patterns and the permanent molar relationships to predict the future malocclusions', Journal of clinical and experimental dentistry, 11(6), pp. e553-e557.

Saarikallio, S. and Erkkilä, J. (2007) 'The role of music in adolescents' mood regulation', Psychology of Music. SAGE Publications, 35(1), pp. 88-109.
Samuel, S. R., Acharya, S. and Rao, J. C. (2020) 'School Interventions-based Prevention of Early-Childhood Caries among 3-5-year-old children from very low socioeconomic status: Two-year randomized trial', Journal of public health dentistry, 80(1), pp. 51-60.

Shives, L. R. (1995) 'Basic Concepts in PsychiatricMental Health Nursing', Gastroenterology Nursing, pp. 197-198. doi: 10.1097/00001610-199509000-00013.

Singh, D. et al. (2014) 'Stress Reduction through Audio Distraction in Anxious Pediatric Dental Patients: An Adjunctive Clinical Study', International journal of clinical pediatric dentistry, 7(3), pp. 149-152.

Stabholz, A. and Peretz, B. (1999) 'Dental anxiety among patients prior to different dental treatments', International dental journal, 49(2), pp. 90-94.

Subramanyam, D. et al. (2018) 'Comparative evaluation of salivary malondialdehyde levels as a marker of lipid peroxidation in early childhood caries', European journal of dentistry, 12(1), pp. 67-70.

Tse, M. M. Y., Chan, M. F. and Benzie, I. F. F. (2005) 'The Effect of Music Therapy on Postoperative Pain, Heart Rate, Systolic Blood Pressure and Analgesic Use Following Nasal Surgery', Journal of Pain \& Palliative Care Pharmacotherapy, pp. 21-29. doi: 10.1080/ j354v19n03_05.

Vignesh, R. et al. (2019) 'Management of Complicated Crown-Root Fracture by Extra-Oral Fragment Reattachment and Intentional Reimplantation with 2 Years Review', Contemporary clinical dentistry, 10(2), pp. 397-401.

Vishnu Prasad, S. et al. (2018) 'Report on oral health status and treatment needs of 5-15 years old children with sensory deficits in Chennai, India', Special care in dentistry: official publication of the American Association of Hospital Dentists, the Academy of Dentistry for the Handicapped, and the American Society for Geriatric Dentistry, 38(1), pp. 58-59. 